\title{
Productivity of Tomato in the Greenhouse Using Bee Pollination
}

\author{
Asiko Grace, Oketch Jane, Mochorwa Jared, Koech Christine, Momanyi Dinah, Nzano Patricia, \\ Palla David, Mc'ligeyo Susan, Okinyi Blaise, Kibe Kamunyu
}

National Beekeeping Institute, Ministry of Agriculture, Livestock and Fisheries, Nairobi, Kenya

Email address:

nbibeekeeping@yahoo.com (A. Grace),gasiko2002@yahoo.com (A. Grace)

To cite this article:

Asiko Grace, Oketch Jane, Mochorwa Jared, Koech Christine, Momanyi Dinah, Nzano Patricia, Palla David, Mc'ligeyo Susan, Okinyi Blaise, Kibe Kamunyu. Productivity of Tomato in the Greenhouse Using Bee Pollination. International Journal of Applied Agricultural Sciences. Vol. 3, No. 6, 2017, pp. 161-165. doi: 10.11648/j.ijaas.20170306.14

Received: September 4, 2017; Accepted: September 28, 2017; Published: December 21, 2017

\begin{abstract}
A green house was installed in October 2014. The aim was to increase tomato productivity in the greenhouse using bee pollination. The tomato plant and fruits in the greenhouse were healthier than those in the open field, attaining a maximum weight of 410 gms, for the tomato. The fruit means were: 213 and 162 gms for the inside and outside, respectively. This was highly significant $(\mathrm{t}=5.39 ; \mathrm{df}=744.2 ; \mathrm{p}<0.001)$. Similarly, the average weights of the first tomato fruits on each branch were: $117 \mathrm{gms}$ and $110 \mathrm{gms}$ in the greenhouse and open field, respectively. The maximum number of fruits per branch in the greenhouse was eleven fruits whereas those on the outside plot were eight. Thus, productivity was higher in the greenhouse plants, with a longer production period, compared to the plants on the outside plot, due to honeybee pollination. Both the greenhouse and outside field plot tomatoes were affected by the tomato leaf miner, Tuta absoluta, with time, curtailing further fruit production.
\end{abstract}

Keywords: Productivity, Greenhouse Technology, Plant Health

\section{Introduction}

Pollination is vital for improved quantity and quality crop and fruit yields [1-6]. Many pollinating agents are involved in the process, especially insects [7-13]. Insect pollinators play a complementary role in obtaining maximum fruit-set [1-2]. A large number of fruits and vegetables, including: Strawberries (Fragaria $x$ ananassa Duch.), Cucumbers (Cucumis sativa Linnaeus), Sweet pepper (Capsicum annum Linneaus), Egg plant (Solanum melongena Linnaeus), Kales (Brassica spp. Linnaeus), Tomatoes (Lycopersicon esculentum Linnaeus), Pumpkin (Cucurbita pepo Linnaeus) and Water melons (Citrulus lanatus Thunb. mansf.), are bee pollinated [8, 4-16]. All these contribute to increased food security [17-20].

\section{Objectives}

a) Enhancing tomato production in a greenhouse using bee pollinators

b) Observation of tomato disease prevalence with time

\section{Study Area}

The study area was the National Beekeeping Institute, Lenana, Coordinates: UTM 37M 0257490, 9858862, in Nairobi, Kenya.

\section{Materials and Methods}

A greenhouse (8x24 Metres) was installed in October 2014 as part of collaborative program between the National beekeeping institute and the EU-AU sponsored Bee Health Project at ICIPE with the aim of enhancing tomato productivity in the greenhouse using bee pollination for increased food security. Only part of the greenhouse $(8 \times 12$ Metres) was used. The test plant was tomato, Lycopersicon esculentum Mill, Corazon variety. The honeybee colony was introduced inside the greenhouse at the onset of flowering as the sole tomato pollinator. The outside field plot was enclosed by a concrete perimeter wall, but allowing a select range of pollinators: butterflies, moths, birds and a limited 
number of bees: solitary and stingless. A Split-plot design was applied [25-26].

Table 1. Activities carried out from nursery to transplanting.

\begin{tabular}{lll}
\hline Date & Activity & Remarks \\
\hline $7 / 10 / 2014$ & Planting seeds on seed bed & Done \\
$8 / 10 / 2014$ to $14 / 10 / 2014$ & Watering by spraying & germination delayed \\
$15 / 10 / 2014$ & Watering by spraying & germination delayed \\
$16 / 10 / 2014$ & Watering by spraying & 10 gms in 16 litres of water \\
$17 / 10 / 2014$ to $19 / 10 / 2014$ & Apply NPK poly feed starter & \\
$20 / 10 / 2014$ & Plain water & 10gms in 16 litres of water \\
$21 / 10 / 2014$ to $23 / 10 / 2014$ & Apply NPK poly feed starter & \\
$24 / 10 / 2014$ & Plain water & 10gms in 16 litres of water \\
$25 / 10 / 2014$ to $27 / 10 / 2014$ & Apply NPK poly feed starter & \\
$28 / 10 / 2014$ & Plain water & transplanting on the open plot was done after one week \\
$30 / 10 / 2014$ & Transplanting in the green house and thereafter on the outside plot &
\end{tabular}

Other activities included: daily irrigation (drip), defoliation and de-suckering, limited application of recommended fertilizer, trellising, checking for diseases/pests, limited spraying, as need arose, with the assistance of a professional and introduction of a honey bee colony for pollination. Transplanted plants were clearly labelled.

\section{Results}

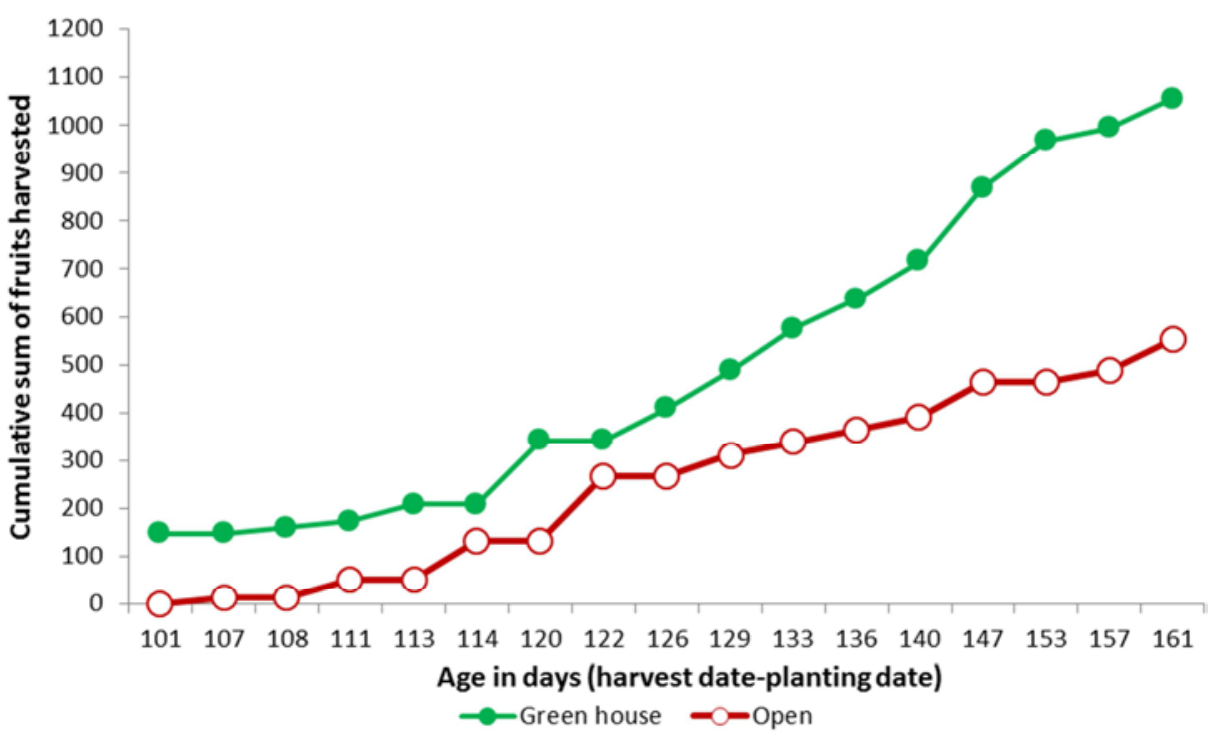

Figure 1. Productivity: Total number of fruits harvested by plant age.

The green house had consistently higher number of yields than open field plot plants, with the gap widening with plant age. The open field plot tomatoes' yield decreased with age, whereas the green house plants had a longer production period.

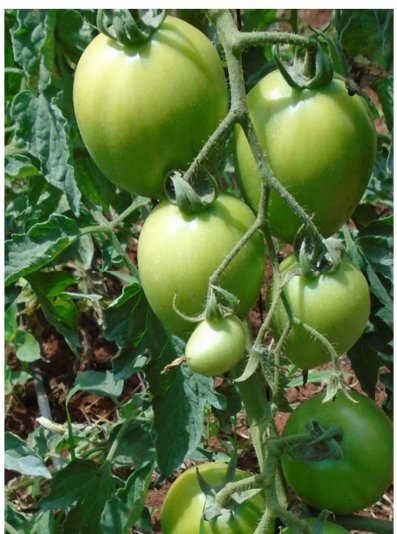

Figure 2. Increased tomato productivity per branch. Photo: Asiko, 2015.
Table 2. Tomato productivity as per plant-age.

\begin{tabular}{llllll}
\hline Parameter & estimate & s.e. & t(*) & t pr. & $\begin{array}{l}\text { Antilog of } \\
\text { estimate }\end{array}$ \\
\hline Constant & -5.67 & 0.776 & -7.3 & $<.001$ & 0.003449 \\
Age_in_days & 0.02836 & 0.00563 & 5.04 & $<.001$ & 1.029 \\
$\begin{array}{l}\text { Location Open } \\
\text { Age_in_days.Location }\end{array}$ & -0.54 & 1.21 & -0.45 & 0.654 & 0.5819 \\
Open & 0.00503 & 0.0088 & 0.57 & 0.568 & 1.005 \\
\hline
\end{tabular}

Table 3. Average weight of harvested fruits.

\begin{tabular}{llll}
\hline Location & Mean & $\begin{array}{l}\text { Standard } \\
\text { deviation }\end{array}$ & $\begin{array}{l}\text { Standard error of } \\
\text { mean }\end{array}$ \\
\hline Green house & 213.4 & 142 & 6.416 \\
Open & 162 & 127.2 & 7.055 \\
\hline
\end{tabular}

The green house had significantly heavier fruits than those in the open field $(\mathrm{t}=5.39 ; \mathrm{df}=744.2 ; \mathrm{p}<0.001)$. 




\section{$\multimap$ Green house $\bullet$ Open}

Figure 3. Average fruit weight by location and stem age.

Tomatoes in the green house reached their peak fruit weight by day 111, compared to the open field plants, which reached their peak weight at day 122. The fluctuation pattern was however, similar for both green house and open field plants. The total weight of tomatoes decreased with plant age.

Table 4. Average weight of first fruit.

\begin{tabular}{llll}
\hline Date & Average WT of $\mathbf{1}^{\text {st }}$ fruit in gms & Grand Total \\
\cline { 2 - 4 } & Green house & Open & 109.75 \\
\hline $16 / 1 / 2015$ & 109.75 & 94.5 & 94.5 \\
$22 / 01 / 2015$ & & & 68.66666667 \\
$23 / 1 / 2015$ & 68.66666667 & 116.7916667 & 116.5151515 \\
$26 / 1 / 2015$ & 115.7777778 & & 177.875 \\
$28 / 1 / 2015$ & 177.875 & 119.1276596 & 119.1276596 \\
$29 / 1 / 2015$ & & & 143.5205479 \\
$4 / 2 / 2015$ & 143.5205479 & 153.308642 & 153.308642 \\
$6 / 2 / 2015$ & & & 142.9333333 \\
$10 / 2 / 2015$ & 142.9333333 & 114.02777778 & 119.2386364 \\
$13 / 2 / 2015$ & 122.8461538 & 104.4 & 116.8181818 \\
$17 / 2 / 2015$ & 121.1754386 & 80.86363636 & 94.72727273 \\
$20 / 2 / 2015$ & 101.6590909 & 80.39285714 & 96.5 \\
$24 / 2 / 2015$ & 107.775 & 79.48275862 & 98.62686567 \\
$3 / 3 / 2015$ & 113.2368421 & & 93.64705882 \\
$9 / 3 / 2015$ & 93.64705882 & 69.55555556 & 86.666666667 \\
$13 / 3 / 2015$ & 103.7777778 & 83.77777778 & 87.15789474 \\
$17 / 3 / 2015$ & 90.2 & 110.4534884 & 114.3988571 \\
Grand Total & 116.9548023 & & \\
\hline & & & \\
& & & \\
\end{tabular}






Figure 4. Disease incidence by locality over time.

Although the number of plants infected by Tuta absoluta, significantly increased over time, there was no difference in disease infestation between the green house and open field plants. The interaction time was also, not significant.

Table 5. Average TOTAL WT (gms).

\begin{tabular}{llll}
\hline $\begin{array}{l}\text { Average TOTAL WT } \\
\text { (gms) }\end{array}$ & & & \\
\hline Date & Green house & Open & Grand Total \\
\hline $16 / 1 / 2015$ & 261.4 & & 261.4 \\
$22 / 01 / 2015$ & & 120.5 & 120.5 \\
$23 / 1 / 2015$ & 121.6666667 & & 121.6666667 \\
$26 / 1 / 2015$ & 171.8888889 & 169.9166667 & 170.4545455 \\
$28 / 1 / 2015$ & 255.2631579 & & 255.2631579 \\
$29 / 1 / 2015$ & & 199.7659574 & 199.7659574 \\
$4 / 2 / 2015$ & 234.4657534 & & 234.4657534 \\
$6 / 2 / 2015$ & & 218.2560976 & 218.2560976 \\
$10 / 2 / 2015$ & 202.8888889 & & 202.8888889 \\
$13 / 2 / 2015$ & 295.2941176 & 173.5 & 229.4594595 \\
$17 / 2 / 2015$ & 186.1964286 & 135.8 & 172.9342105 \\
$20 / 2 / 2015$ & 149.9642857 & 91.55 & 125.625 \\
$24 / 2 / 2015$ & 221.275 & 80.39285714 & 163.2647059 \\
$3 / 3 / 2015$ & 291.4736842 & 119.9259259 & 220.2153846 \\
$9 / 3 / 2015$ & 166.0588235 & & 166.0588235 \\
$13 / 3 / 2015$ & 141.8888889 & 85.66666667 & 113.7777778 \\
$17 / 3 / 2015$ & 164 & 177.4814815 & 170.3859649 \\
Grand Total & 213.4142857 & 162 & 192.9116564 \\
\hline & & & \\
\hline
\end{tabular}

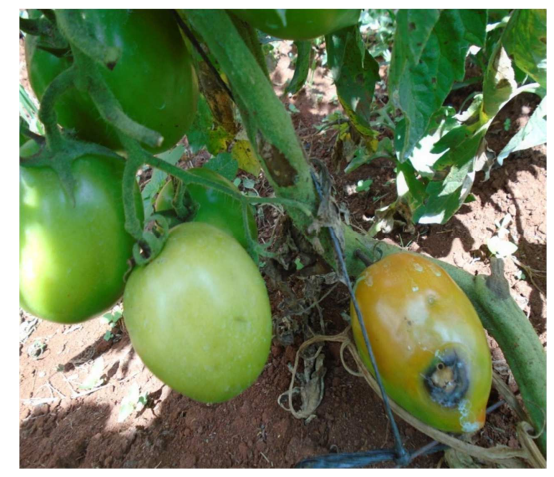

a



Figure 5. Damaged tomato fruit by Tuta absoluta. Photo: Asiko, January, 2015

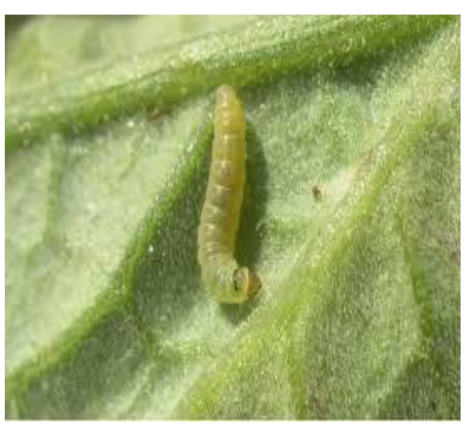

a



Figure 6. Caterpillar a, with damage on tomato leaf, b. Photo: Asiko, 2015. 


\section{Conclusions}

The tomato fruits inside the greenhouse were significantly heavier, with a maximum weight of $410 \mathrm{gms}$, than those in the open field plot $(\mathrm{t}=5.39 ; \mathrm{df}=744.2 ; \mathrm{p}<0.001)$. The inside tomatoes too, were healthier than those in the open field, with the means, 213 and 162 gms, for the inside and outside, respectively. Fruit productivity was higher in the greenhouse, expressed in the number of tomatoes per branch, Figure 2. A maximum of 11 tomatoes was recorded in the greenhouse compared to 8 , on the outside plot. This concurs with Slaa's experiments on bees in applied pollination [7] and several other scientists [1-13]. There was fluctuation in the average weights of the first fruit, $117 \mathrm{gms}$ in the greenhouse and 110 gms, in the open field plot. Field plot tomato production decreased significantly with plant-age. The greenhouse tomatoes had a longer production period, before being curtailed by the tomato leaf miner, Tuta absoluta, which equally affected the field tomatoes.

The greenhouse technology, combined with honeybee pollination impacted positively on tomato production. This impact was significant, evidenced in quantity and quality. The perimeter wall surrounding the outside field plot deterred a number of efficient and effective pollinators to the tomato plant.

\section{Acknowledgements}

Ministry of Agriculture, State Department of Livestock, through the Director, Mr. Julius Kiptarus and the Principal Secretaries, Prof. Fred Segor and Andrew Tuimur, for financial support.

ICIPE, AU/EU Sponsored Bee Health Program.

Staff, National Beekeeping Institute particularly Clare Tamana, for assisting in typesetting and Kennedy Wekalao, in field work.

\section{References}

[1] Free J. B, 1968a. The pollination of strawberries by honeybees. Journ. of hort. Scie. 43.

[2] Free J. B, 1968b. Foraging behaviour of Honey bees (Apis mellifera) and Bumble bees (Bombus sp.) on black currant (Ribes nigrum), raspberry (Rubus idaeus) and strawberry (Fragaria Chiloensis $x$ ananassa) flowers. Journ. of Animal behaviour 15: 134-144.

[3] Free J. B, 1993. Insect pollination of cultivated crops, $2^{\text {nd }}$ Edition, University of Wales, Cardiff. U.K. Academic Press, New York.

[4] Connor, L. J, 1970. Studies of strawberry pollination in Michigan. Pp 157-162 in The indespensable Pollinators. University of Arkansas Agri. Ext. serv. Publ. MP 127. 233 p.

[5] Crane E and Walker P, 1984. Pollination directory for world crops, International Bee Research Association, Bucks, London.

[6] Crane E, 1992. The Past and Present status of beekeeping with stingless bees. Bee world 73: 29-42.

[7] Ester Judith Slaa, Luis Alejandro Sa'nchez Chaves, Katia
Sampaio Malagodi-Braga, Frouke Elisabeth Hofstede, 2007. Stingless bees in applied pollination: practice and perspectives

[8] Asiko G. A, Nyamasyo G. N and Kinuthia W, 2007. Domestication of stingless Bees (Meliponula sp. and Hypotrigona $s p$.) for Sustainable Livelihoods in Kenyan Communities. $9^{\text {th }}$ International pollination symposium on plantpollinator relationships. June 24-28, 2007. Ames, Iowa, USA.

[9] Kiatoko N, Raina S. K, Muli E, Mueke J, 2014. Enhancement of fruit quality in Capsicum annum through pollination by Hypotrigona gribodoi, in Kakamega, Western Kenya.

[10] Faegri K and Van Der Pijl, 1971. The principles of Pollination Ecology. Pergamon Press, New York, U.S.A.

[11] Roubik D. W, 1989. Ecology and natural history of tropical bees. Cambridge, UK: Cambridge University press.

[12] Roubik D. W, 1995. Pollination of cultivated plants in the tropics, FAO Agricultural services bulletin. No.118, Rome, Italy. $196 \mathrm{Pp}$.

[13] Buchmann S. L, 1995. Pollen, anthers and dehiscence in pollination of cultivated plants in the tropics, Ed Roubik D. W, pp 121-23. Rome: F. A. O.

[14] Procter M, Yeo P and Lack A, 1996. The natural history of pollination. Harper Collins Publishers.

[15] Michener C. D, 2000. The bees of the world. John Hopkins University press.

[16] Dafni A, Kevan P. G and Husband B. C, 2005. Practical Pollination Biology. Enviroquest, LTD. Cambridge, Ontario, Canada.

[17] Ohio State University Bulletin, 2006. Bee Pollination of crops in Ohio. Bulletin 559.

[18] Wille A, 19 83. Biology of the stingless bees. Annu. Rev. Entomol. 28:41-64.

[19] Njoroge G. \& Gikungu M, 2006. Status of threatened stingless bees and their conservation strategies for poverty alleviation and sustainable utilization in Semi-Arid areas of Mwingi, Kenya. RPSUD Research Report.

[20] Dino J Martins, 2014. Our friends, the pollinators. A handbook of pollinator diversity and conservation in East Africa.

[21] Ministry of Agriculture and Rural Development, 2003. Fruits and vegetables, technical handbook. Revised Edition, 2003, AIRC, Nairobi.

[22] Kioko E; Muthoka P; Gikungu M and Malombe I, 2006. Conservation of useful insects and their food plants for ecodevelopment in dryland Districts of Eastern Kenya. Report. RPSUD Research Report.

[23] Kinuthia W, 2007. Pollinators as an indicator of ecosystem health: A landscape approach to biodiversity conservation. Poster, Wildlife Conference: Research imperative for biodiversity conservation \& management. 18-20 April 2007, Nairobi Kenya.

[24] Delaplane K. S and Mayer D. F, 2000. Crop pollination by bees. CABI Publishing.

[25] Trigiano R and Gray D, 2000. Plant tissue culture concepts and laboratory exercises, $2^{\text {nd }}$ edition.

[26] Compton M. E, 1994. Statistical methods suitable for the analysis of plant tissue culture data. Review paper. Plant cell tissue and organ culture 37: 217-242, Kluwer academic Publishers. 